\title{
A CASE OF CUSHING'S SYNDROME IN AN INFANT
}

\author{
BY \\ E. GOLDBLATT and A. H. SNAITH \\ From The Hospital for Sick Children, Great Ormond Street, London
}

(RECEIVED FOR PUBLICATION JUNE 2, 1958)

Cushing's syndrome is rare in infancy. The present case is reported because of the unusual pathology and because to our knowledge this is the first case in which bilateral adrenalectomy has been carried out in an infant.

\section{Case History}

The patient, a girl, was born after a normal full-term pregnancy. Her birth weight was $8 \mathrm{lb} .4 \mathrm{oz}$. (75th percentile) and at 12 months, when she was apparently normal, her weight was $24 \mathrm{lb}$ (75th percentile). Two months later she was brought to hospital because of her rapid gain in weight and increasing irritability. During this period she had gained $4 \mathrm{lb}$. $14 \mathrm{oz}$. and weighed $28 \mathrm{lb} .14 \mathrm{oz}$. (97th percentile). Thus the onset of her condition was short and dramatic (Figs. 1 and 2).

On examination (Fig. 2) she was obese, with a buffalo hump, her face was plethoric and she had an acneiform rash. There was slight hirsutes of the face and back. No striae were present. She had a small umbilical

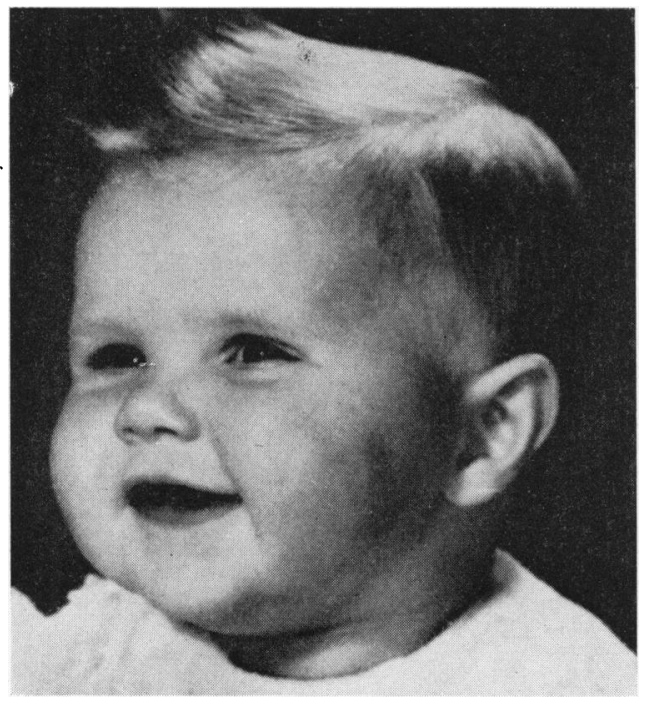

Fig. 1.-Apparently normal at 8 months old. hernia. The height was 30 in. and the span 301 in. (50th percentile). The blood pressure was $140 / 90 \mathrm{~mm}$. $\mathrm{Hg}$ (normal average $96 / 66 \mathrm{~mm}$. $\mathrm{Hg}$ ). On radiographic examination the bone age was normal and there was no osteoporosis of the spine, skull or long bones. An intravenous pyelogram suggested that there might be enlargement of the right adrenal. Glucose tolerance test: fasting blood sugar, $89 \mathrm{mg}$. \%; sugar readings were $111,111,117,137$ and $125 \mathrm{mg}$. \%. The serum sodium was $147 \mathrm{mEq} . / 1$, the serum potassium $4.4 \mathrm{mEq} . / 1$, the blood cholesterol $154 \mathrm{mg}$. \%; serum proteins were $7 \cdot 0 \mathrm{~g} . \%$ and the $\alpha$ and $\gamma$ globulins were slightly raised. The haemoglobin was $110 \%(16 \cdot 3 \mathrm{~g} . \%)$, and the white count normal except that no eosinophils were present. R.B.C. were 4,720,000/c.mm. Details of steroid excretion are given in Table 1 .

In the expectation that an adrenal tumour would be found an exploratory laparotomy was undertaken by Mr. D. Innes Williams. Cortisone $25 \mathrm{mg}$. per day was given orally in divided doses for two days prior to the operation. Both adrenal glands were found to be slightly enlarged and nodular. The left adrenal was

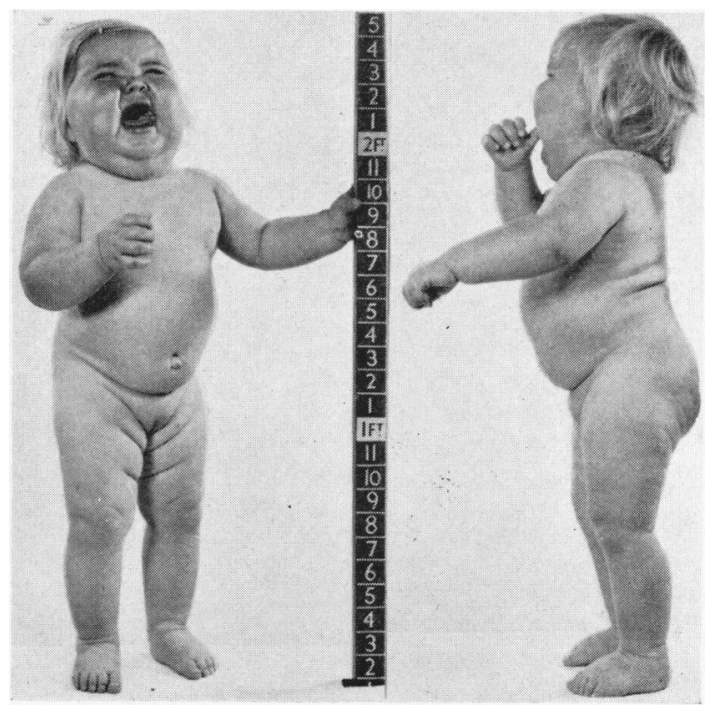

FIG. 2.-On admission aged 14 months. 
TABLE 1

STEROID EXCRETION IN GIRL AGED 14 MONTHS WITH CUSHING'S SYNDROME DUE TO BILATERAL MULTIPLE ADRENOCORTICAL ADENOMATA

\begin{tabular}{|c|c|c|c|}
\hline Stage and Treatment & $\begin{array}{l}\text { 17-Keto- } \\
\text { steroids } \\
(\text { mg. } / 24 \text { h.) }\end{array}$ & $\begin{array}{l}\text { 17-Hydroxy- } \\
\text { steroids } \\
\text { (mg./24 hr.) }\end{array}$ & $\begin{array}{l}\text { 17-Ketogenic- } \\
\text { steroids } \\
\text { (mg./24 hr.) }\end{array}$ \\
\hline $\begin{array}{l}\text { Normal for age } \\
\text { Before first operation ... } \\
\text { Following removal of }\end{array}$ & $\begin{array}{l}0 \cdot 5 \\
2 \cdot 9\end{array}$ & $\begin{array}{l}1 \cdot 2 \\
9 \cdot 7\end{array}$ & $\begin{array}{r}2 \cdot 0 \\
21 \cdot 3\end{array}$ \\
\hline $\begin{array}{l}\text { left adrenal } \\
\text { After } 5 \text { days of: }\end{array}$ & $2 \cdot 4$ & $4 \cdot 2$ & $6 \cdot 0$ \\
\hline $\begin{array}{l}\text { ACTH } 25 \mathrm{mg} \text {./day } \\
\text { 9- } a \text {-fluorohydrocorti- }\end{array}$ & $2 \cdot 9$ & $9 \cdot 9$ & $15 \cdot 8$ \\
\hline $\begin{array}{l}\text { sone } 500 \mu \mathrm{g} \text {. b.d. . } \\
\text { Methyl testosterone }\end{array}$ & $1 \cdot 6$ & $10 \cdot 4$ & $7 \cdot 5$ \\
\hline $\begin{array}{l}10 \mathrm{mg} . / \mathrm{day} \\
\text { Stilboestrol } 1 \mathrm{mg} \text {, per }\end{array}$ & $3 \cdot 4$ & $3 \cdot 4$ & $8 \cdot 8$ \\
\hline $\begin{array}{cc}\text { day } \\
\text { day }\end{array}$ & $2 \cdot 4$ & $3 \cdot 8$ & $6 \cdot 0$ \\
\hline
\end{tabular}

Before operation aldosterone excretion was $<2 \mu \mathrm{g} . / 24$ hours total oestrogen excretion $<1.0 \mu \mathrm{g}$. $/ 24$ hours and urinary gonadotrophins $<5 \mathrm{~m} . \mu . / 24$ hours (within normal limits).

removed (Figs. 3, 4a and 4b). The liver was large and fatty. There was a moderate hypokalaemic alkalosis for the first week after operation, during which time $1 \mathrm{~g}$. of potassium chloride per day was given and cortisone was continued in the same dosage as before. Otherwise, the post-operative course was uneventful. After further investigation it was decided to remove the right adrenal. The day before the second operation $50 \mathrm{mg}$. of cortisone were given by mouth and on the day of the operation $50 \mathrm{mg}$. b.d. of cortisone were given intramuscularly. The post-operative course was uneventful, cortisone was gradually reduced and the patient was discharged two months later, by which time her appearance had become

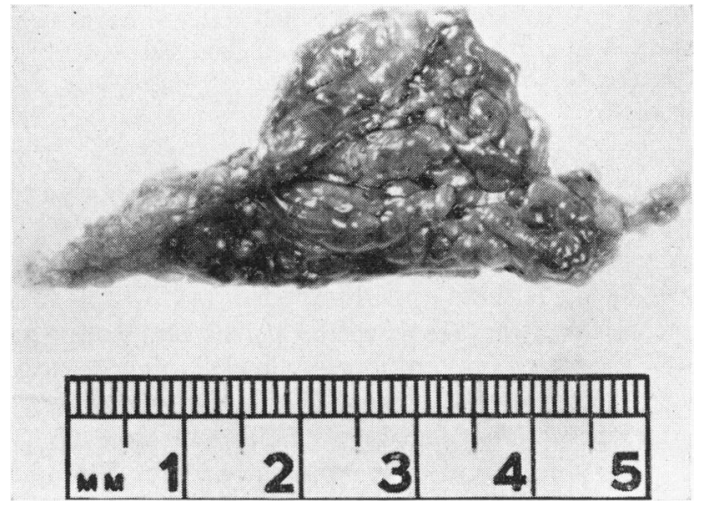

FIG. 3.-Left adrenal. Note multiple nodules.

much more normal. At present she is being maintained on $20 \mathrm{mg}$. of cortisone acetate and $1 \mathrm{~g}$. of salt a day. Three months after discharge from hospital she was again admitted, suffering from avulsion of two finger tips which she had caught in a train door. She withstood this trauma without any evidence of metabolic upset.

Further Investigations. After removal of the left adrenal there was a decline in steroid excretion but the clinical condition remained unchanged. The influence of ACTH, fluorohydrocortisone, methyl testosterone and of stilboestrol on steroid excretion was then studied (Table 1) and it was concluded that none of these hormones, in the dose given, strikingly influenced secretion by the remaining gland. The great increase in

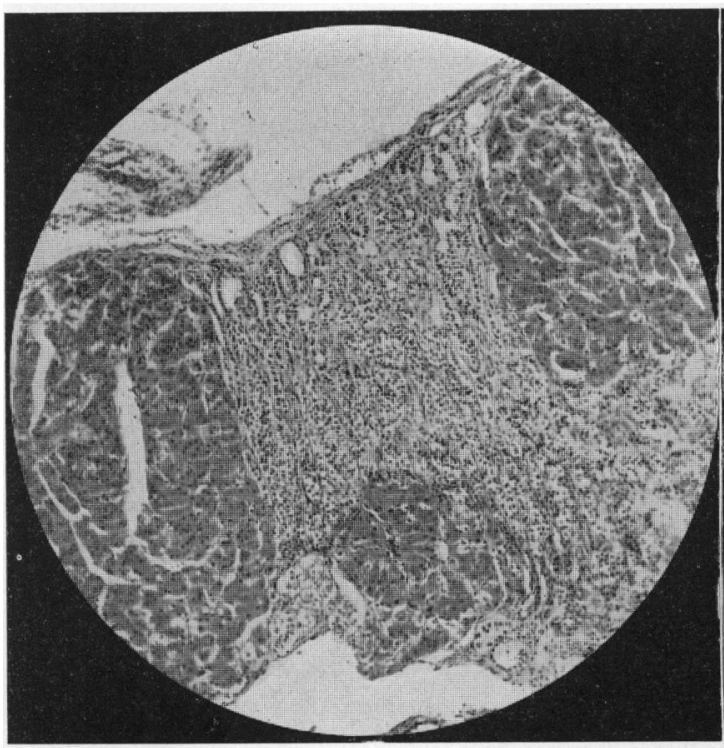

(a)

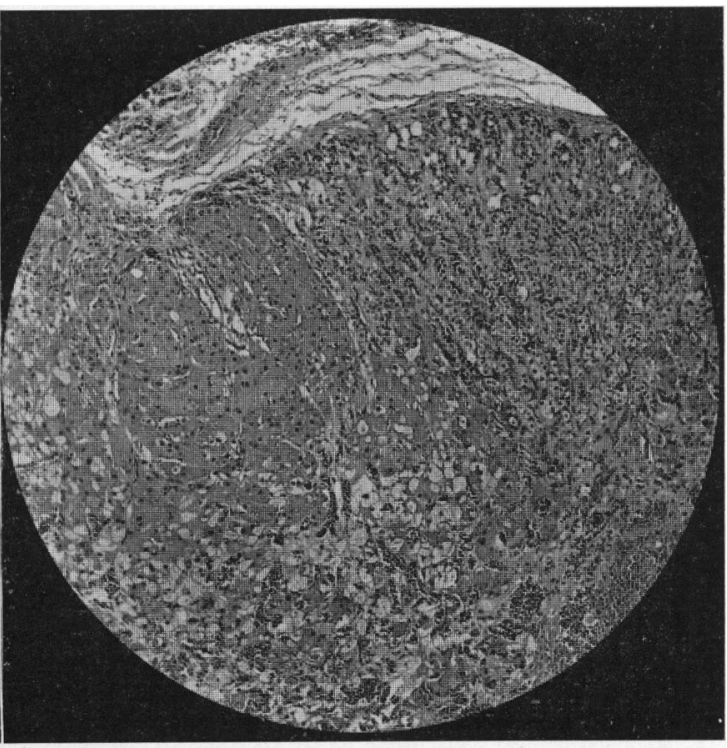

(b)

Figs. $4 a$ and $4 b$.-Photomicrographs of adrenal glands $\times 60$, illustrating multiple adenomatous nodules and intervening areas of atrophic cortical tissue. 
17-hydroxysteroid excretion which might have been expected in a case of adrenal hyperplasia did not occur after the administration of A.C.T.H.

\section{Discussion}

In children Cushing's syndrome is usually due to tumour (Guin and Gilbert, 1956); a case of adrenal hyperplasia has recently been described in a child aged $8 \frac{1}{2}$ by Hubble and Illingworth (1957) and in a case of the same age reported by Chute, Robinson and Donohue (1949) multiple bilateral adenomatous nodules of the type present in this case were found at autopsy. The aetiology of adrenal hyperplasia with Cushing's syndrome remains obscure. Elevated blood ACTH levels have not been demonstrated and it is possible that the adrenal glands are unduly sensitive to ACTH. Jailer, Longson and Christy (1956) have suggested that the pituitary secretes in excess a hypothetical corticotrophin-potentiating substance. The response to ACTH administration in the present case was moderate, and the histological appearance of normal adrenocortical cells adjacent to nodules of abnormal cells could be compatible with the view that secretion by the abnormal cells was in fact to a large extent autonomous.

In view of the age of the patient the possibility that the hyperplastic glands were the result of abnormal development of the foetal cortices was considered. It has been suggested that the human foetal cortex may be dependent upon pituitary gonadotrophins, as is the ' $\mathrm{X}$ ' zone in the mouse (Chester Jones, 1957). No change in steroid excretion was observed to follow the administration of stilboestrol or methyl testosterone, which might have been expected to suppress gonadotrophin secretion. No gonadotrophins could be detected in the urine.

Irradiation of the pituitary gland was not considered appropriate treatment in view of the age of the patient, since to be effective such treatment might interfere with the secretion of other trophic hormones; moreover the response to ACTH did not indicate that a diminution of ACTH secretion would necessarily be of great benefit.

Adrenal enucleation is a procedure which may be successfully carried out in the rat, a new cortex regenerating from solitary cortical cells which adhere to the capsule (Chester Jones, 1957). Such a procedure, if practicable, would have been of interest in this patient since it might have been observed whether normal or abnormal cells regenerated, and thus, perhaps, some light might have been thrown on the fundamental aetiological problem in adrenal hyperplasia. However, it does not seem surgically possible to remove the cortex so as to leave the capsule behind as an intact bag, as in the rat. Furthermore, there is some doubt whether adrenal regeneration occurs after enucleation in the human subject (Dempster, 1955). Consequently, total adrenalectomy, which is the treatment of choice in the older patient was undertaken here with the intention of maintaining the patient on cortisone for the rest of her life. The long-term prognosis remains to be seen (Fig. 5).

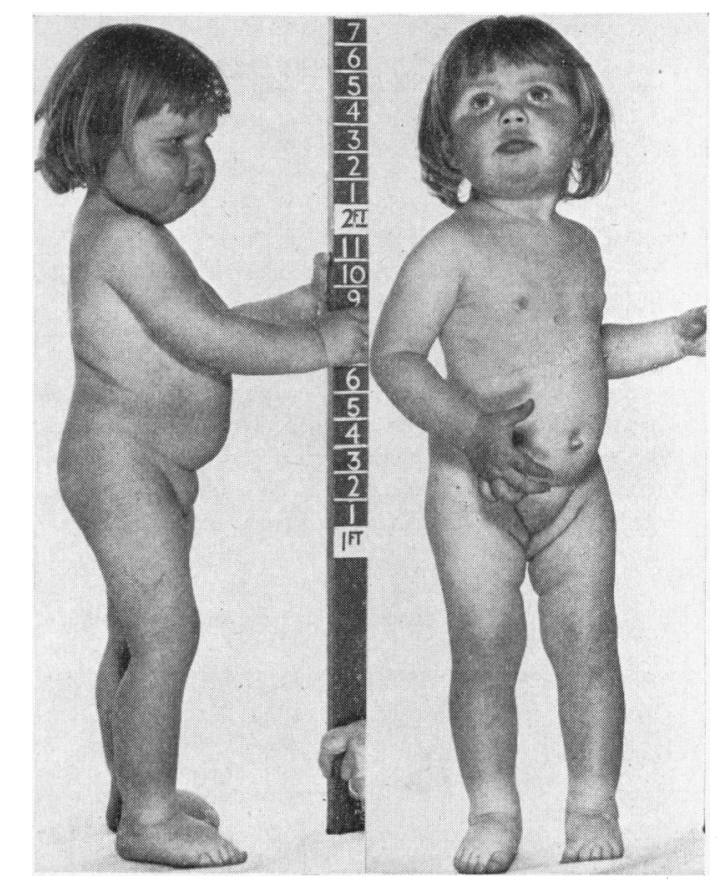

Fig. 5.-Five months after total bilateral adrenalectomy.

We wish to thank Dr. A. P. Norman for permission to publish this case, Dr. I. Chester Jones with whom we discussed the possibility of adrenal enucleation for his advice, and Mr. Derek Martin, of the Department of Medical Illustration, for the photographs.

\section{REFERENCES}

Chute, A. L., Robinson, G. C. and Donohue, W. L. (1949). J. Pediat, 34, 20.

Dempster, W. J. (1955). Brit. J. Surg., 42, 540.

Guin, G. H and Gilbert, E. F.(1956). A.M.A.J. Dis. Child., 92, 297. Hubble, D. V. and Illingworth, R. S. (1957). Arch. Dis. Childh., $32,285$.

Jailer, J. W., Longson, D. and Christy, N. R. (1956). J. Clin. Endocr., 16, 1276.

Jones, I. Chester (1957). The Adrenal Cortex, p. 112 Cambridge. 